\title{
CONFLITO E CONSTRUÇÃO DE RISCOS NA SOCIEDADE COMPLEXA E GLOBALIZADA: O CASO DA DERIVA DO HERBICIDA 2,4-D
}

\author{
CONFLICT AND CONSTRUCTION OF RISKS IN THE COMPLEX AND GLOBALIZED \\ SOCIETY: THE CASE OF 2.4-D HERBICIDE DRIFT
}

\section{Haide Maria Hupffer}

Pós-doutora em Direito pela Unisinos. Doutora em Direito e Mestre em Direito pela Unisinos. Especialista em Recursos Humanos e Graduada em Direito pela Unisinos. Graduada em Ciências Contábeis pela Fundação Machado de Assis agregada a PUCRS. Atualmente é professora e pesquisadora no Programa de Pós-Graduação em Qualidade Ambiental e no Curso de Graduação em Direito da Universidade Feevale.

E-mail: haide@ feevale.br

\section{João Alcione Sganderla Figueiredo}

Possui graduação em Filosofia pela Faculdade de Filosofia Nossa Senhora da Imaculada Conceição (1999), Mestrado em Ciências Sociais (PUC -RS) e Doutorado em Sociologia - Universidad Complutense de Madrid (2008).

Atualmente é Pró-reitor de Pesquisa, Pós-graduação e Extensão e professor pesquisador da Universidade

Feevale no Programa de Doutorado e Mestrado em Qualidade Ambiental e Mestrado em Administração.

E-mail: sganfigue@feevale.br

\section{André Rafael Weyermüller}

Pós-doutor em Direito pela PUC-Rio. Doutor em Direito pela Unisinos. Mestre em Direito Público pela Unisinos. Especialista em Direito Ambiental pela Feevale. Bacharel em Ciências Jurídicas e Sociais pela Unisinos.

Pesquisador no programa de pós-graduação da Universidade Feevale. Professor no mestrado profissional em Indústria Criativa e no mestrado acadêmico em Qualidade Ambiental da Feevale. Docente permanente no Mestrado Profissional em Direito da Empresa e dos Negócios da Unisinos. Professor na graduação em Direito da Feevale e da Unisinos. Professor do Prasjur da Unisinos.

E-mail: andrerw@feevale.br

Recebido em: 15/08/2019

Aprovado em: 27/04/2020

RESUMO: O desenvolvimento da agricultura, baseado hoje no uso indiscriminado de agrotóxicos, criou uma nova realidade em que a dependência da própria tecnologia representa um risco futuro, na medida em que não se pode precisar até que ponto ela irá compensar os passivos ambientais criados para o seu desenvolvimento. Organizou-se o artigo a partir de teóricos que trabalham a temática da globalização policêntrica dos riscos ambientais e o difícil diálogo entre tecnologia, ciência, economia, política e meio ambiente para, com estes subsídios, observar o conflito entre produtores de uvas e produtores de soja do estado do Rio Grande do Sul sobre os efeitos da deriva do herbicida 2,4-D para cultivares de culturas sensíveis, como base fática para uma reflexão. A análise evidenciou que há um conflito que deixou de ser silencioso e que ganhou novos contornos ao envolver produtores agrícolas em lados opostos. As primeiras ações tomadas pelo Sistema Político remetem apenas ao aplicador do produto das lavouras de soja a responsabilidade, enquanto 
que, para a grande indústria produtora de agrotóxicos não recai nenhuma ação. Decisões como a de não responsabilizar o fabricante do herbicida 2,4-D pelos danos da deriva às culturas sensíveis são aceitas pelo fato de que a exigência posta pelo mercado não é uma exigência moral, mas sim, é institucionalizada e amparada pelo sistema legal e político.

Palavras-chave: Percepção de Risco; Agrotóxico; Herbicida 2,4-D; Efeitos da Deriva; Vitivinicultura.

ABSTRACT: The development of agriculture, based today on the indiscriminate use of pesticides, has created a new reality in which dependence on technology itself represents a future risk, as it's impossible to assure how it will compensate the environmental impacts created for its development. The article was organized from theorists who deal about the polycentric globalization of environmental risks and the difficult dialogue between technology, science, economics, politics and the environment so that, with these bases, to observe the conflict between grape producers and soybean producers in Rio Grande do Sul on the effects of 2.4-D herbicide drift for susceptible crop cultivars, as a basis for reflection. The analysis showed that there is a conflict that has ceased to be silent and has gained new contours by engaging agricultural producers on opposite sides. The first actions taken by the political system refer the responsibility only to the product applicator of soybean crops, while for the large agrochemical producing industry there is no action. Decisions such as not to blame the manufacturer of the herbicide 2.4-D for the damage of drift to sensitive crops are accepted because the market doens't demand a moral requirement, but rather it is institutionalized and supported by the legal and political system.

Keywords: Risk Perception; Pesticide; Herbicide 2.4-D; Drift effects; Viticulture.

SUMÁRIO: Introdução. 1 A globalização policêntrica dos riscos ambientais. 2 Os riscos ecológicos do desenvolvimento da tecnociência. $3 \mathrm{O}$ difícil diálogo entre tecnologia, ciência, economia e meio ambiente. 4 A percepção de risco da deriva do herbicida 2,4-D. Conclusão. Referências.

\section{INTRODUÇÃO}

A exacerbação da degradação ambiental tem forte conexão com o processo de desenvolvimento tecnológico, abalando a segurança das instituições e a credibilidade da ciência. Os reflexos na distribuição dos riscos ambientais mostram que o processo de globalização é policêntrico, o que vem a incrementar a complexidade da realidade.

O uso de agrotóxicos se deu de forma cumulativa após a Segunda Guerra Mundial e hoje se encontra em um patamar alarmante e umbilicalmente ligado ao risco, com consequências muito mais profundas e peculiares, as quais certamente repercutem de maneira definitiva na relação do homem com o meio ambiente, além de definir uma realidade com especificidades próprias da atualidade, gerando diversos problemas de saúde e contaminação de solos com efeitos devastadores nos organismos vivos.

Este estudo busca refletir sobre as seguintes realidades: o sistema dos expertos (científicos) que criam agrotóxicos cada vez mais potentes, o sistema econômico que os produz, comercializa e os aplica, o sistema político que libera a comercialização e o uso no Brasil e a realidade da vida, tendo como cenário o conflito entre porteiras instalado no estado do Rio Grande do Sul entre produtores de soja e produtores de uvas.

Para atingir os objetivos propostos, a investigação analisou fontes bibliográficas interdisciplinares para compreender o difícil diálogo entre tecnologia, ciência, economia e meio ambiente sobre riscos. Utilizou-se também de notícias publicadas em sites oficiais e na imprensa 
sobre o conflito instalado no estado do Rio Grande do Sul, entre produtores de soja e produtores de culturas sensíveis, em relação aos danos causados pela deriva do herbicida 2,4-D nos vinhedos gaúchos que serviu como subsídio para confirmar a hipótese inicial de que há um hiato entre a percepção/omissão de risco em relação aos agrotóxicos pelo Estado quando libera o agrotóxico para utilização e comercialização no Brasil e a contaminação ambiental percebida pela sociedade. Portanto, este estudo apresenta, discussões selecionadas como base fática para (re)pensar o papel do sistema político e sistema da ciência no contexto complexo da sociedade de risco e da economia globalizadas. Portanto, o tema foi organizado a partir do estudo caso e das primeiras ações adotadas neste Estado.

A pesquisa é de natureza qualitativa, exploratória e descritiva. A construção do estudo segue um caminho dedutivo, partindo de contextualizações gerais sobre o processo de globalização dos riscos ambientais, para na sequência examinar os riscos ecológicos do desenvolvimento da tecnociência como base para compreender como se dá o diálogo entre Tecnologia, Ciência e Meio Ambiente na sociedade de risco global na percepção dos principais teóricos. A fundamentação teórica precederá a análise das principais discussões sobre os efeitos da deriva do agrotóxico 2,4D na produção de culturas sensíveis, em especial de vinhedos, de forma a dar significado à análise. A dialética está presente no estudo, em especial quando traz a percepção de risco dos produtores de uvas.

\section{A GLOBALIZAÇÃO POLICÊNTRICA DOS RISCOS AMBIENTAIS}

Os riscos ambientais têm potencial de sacudirem os cimentos das sociedades modernas pela característica de se deslocarem, invadirem fronteiras, atravessarem continentes e comportarem danos sem limites, globais, incalculáveis e irreparáveis ao meio ambiente. Essa percepção de Beck (2008) é um alerta para a crescente exportação invisível de perigos e riscos ambientais, ou seja, eles cruzam fronteiras sem serem detectados e seus efeitos podem ser no longo prazo. A missão da sociedade de risco é ingrata, pois está diante de algo que não se sabe e tem que decidir sobre a vida ou a morte "basándose de manera más o menos confessa em el no-saber" (BECK, 2008, p. 83-84).

Um futuro que precisa ser planejado com base no reconhecimento de que existe uma espécie de névoa pairando sobre a sociedade e sobre um planeta "negativamente globalizado", como classifica Bauman (2008, p. 129), num contexto de estreita interdependência, a insegurança reside também nas ações dos outros, sujeitos indeterminados ou indetermináveis que podem atuar negativamente e afetar de forma imprevisível àqueles que não os conhecem e que não conseguem identificar. Os riscos tornam-se, assim, parte da realidade e submetem a condição humana às incertezas do futuro, o qual não pode mais ser objeto de controle efetivo, sobretudo em virtude da impossibilidade de precisar sua ocorrência, alcançadas por meio de um cálculo de probabilidades típico de um mundo rotineiro.

Em um mundo negativamente globalizado os efeitos das decisões e ações são transtemporais, transterritoriais, invisíveis e geralmente irreversíveis, se propagando "muito além do alcance do impacto rotinizante do controle, assim como do escopo do conhecimento necessário para planejá-lo". Não conseguir elaborar o cálculo probabilístico dos perigos é uma das razões para tornar o mundo tão vulnerável, principalmente, porque se está diante de um "ambiente que é, em princípio, irregular, onde as consequências interrompidas e a não-repetição de sequências se tornam a regra, a anormalidade, a norma. A incerteza sob um nome diferente" (BAUMAN, 2008, p. 129).

Edgar Morin (2010) destaca a ideia de ambivalência em relação aos benefícios e malefícios do desenvolvimento baseado na ciência. Os perigos aos quais a humanidade se expôs (porque os produziu) andam junto com uma gama de benefícios trazidos pelo desenvolvimento e pela técnica. Essa ambivalência geral do século atual é resultado dessa avaliação entre o bom e o negativo, entre aquilo que veio como benefício indiscutível e aquilo que foi criado como um grande risco presente e futuro. A dificuldade está, segundo Morin (2002, p. 50-51), em “comparar duas 
verdades profundas, ou seja, considerar a ciência como ambivalência”. Essa ambivalência geral se refere assim a uma observação do fenômeno como um todo, resgatando o aspecto histórico e fazendo-se um comparativo com a atualidade. A ambivalência é relacionada a todo o processo, incluindo-se tanto a perspectiva da construção da realidade histórica quanto a perspectiva mais específica relacionada com a ciência e com a técnica.

Essa realidade indica que a noção de fronteiras está cada vez mais relativizada e com uma importância cada vez menor no contexto de globalização que hoje se vivencia. Sendo esse fenômeno, cada vez mais sinônimo de uma universalização, a noção de barreiras políticas fica mais frágil e desimportante. A ambivalência destacada por Morin (2002) é bastante evidente em relação às questões relativas ao meio ambiente, posto que toda a ação humana no sentido do desenvolvimento está de alguma maneira ligada ao Sistema da Economia e, assim, ligada à utilização dos recursos naturais. Assim, é possível afirmar que os aspectos negativos do processo, sobretudo ambientais, se estendem pelo planeta como um todo, não havendo barreiras eficazes para conter os riscos, sendo correto afirmar que "estamos diante de problemas que desafiam a inteligência humana e cobram respostas rápidas, porque é a própria existência humana que está em perigo" (EFKEN, 2005, p. 123).

A insegurança passa a não ter fronteiras na mesma proporção que as possibilidades positivas se estendem sem restrições importantes. O próprio capital "viaja leve" (BAUMAN, 2001, p.70) e depende apenas de computador ou um celular e assim pode se instalar e se retirar com grande facilidade, levando a consequências imprevisíveis. A ambivalência dessa relação é inegável e compõe um extrato importante da realidade que se pretende delimitar no espaço da presente pesquisa.

Além de ambivalente, o processo de globalização é policêntrico, o que vem a incrementar a complexidade da realidade. É policêntrica porque são superados os limites regionais, constituindo o que Gunther Teubner (2005, p. 86-88) designa por "setores globais autônomos" que transformam o processo em um fenômeno multidimensional que foge ao controle único dos Estados, privilegiando as organizações internacionais.

Em decorrência da extensa gama de fatores de risco que com a globalização se tornam mais abrangentes e complexos, a realidade pode ser compreendida a partir de alguns fatores de risco bem específicos que submetem a sociedade global à insegurança e indicam a necessidade de uma reformulação dos mecanismos tradicionalmente construídos pelo Estado (e pelo Direito) para dar conta dessa realidade. Assim, o uso indiscriminado de agrotóxicos pode ser pontuado como um fator de risco para a humanidade.

Observa-se, neste contexto, que a sociedade atual vivencia uma realidade complexa em que a contingência ("O risco é a contingência: uma decisão sempre implica a possibilidade de que as suas consequências ocorram de maneira diferente", ROCHA, 2005, p. 39) e as possibilidades de conformação do futuro estão intimamente relacionadas às decisões que precisam ser tomadas no presente em relação ao futuro, decisões que podem significar tanto vantagens quanto desvantagens, progresso ou ruína (BECK, 2008, p. 21). As preocupações com a economia mundial, as novas tecnologias e com o terrorismo, que continua ganhando força (BAUMAMN, 2008, p. 133), ocupam grande parte da pauta internacional e representam novas formas de riscos com as quais a humanidade precisa aprender a lidar, adaptando-se e revendo as formas de encaminhamento desses problemas, uma vez que o afastamento completo dos riscos é impossível. As necessidades de produção de alimentos e energia, promoção de segurança, enfrentamento das consequências das mudanças climáticas, crise financeira e acesso à água são fatores de risco que implicam em aceitar a realidade como composta de múltiplas possibilidades, até porque são demandas produzidas pela sociedade a qual, segundo Niklas Luhmann (1992), produz tudo e onde tudo que acontece somente acontece na sociedade.

Neutzling e Andrade (2009) lançam severas críticas ao novo modelo de domínio tecnológico que se baseia na "destruição criativa" em que as inovações suplantam as anteriores em 
termos tecnológicos, sucateando as anteriores para serem assim substituídas por novas e sempre mais novas inovações. Neste contexto, também estão os agrotóxicos, que se instalaram com força após a Segunda Guerra Mundial e com potencial destrutivo.

Não bastassem essas questões, a problemática ambiental é, na mesma medida, preocupante e representativa de uma época, de uma realidade profundamente marcada pelos extremos e pelas inúmeras possibilidades sobre as quais não se tem o controle que se esperava que tivesse no passado, em que a crença e a confiança na tecnologia promovia (e ainda promove em grande medida) uma falsa sensação de segurança. Tanto o Estado, em suas várias configurações, quanto a economia, em suas diversas formas e graus de autonomia, não mais podem oferecer, isolados, as respostas (ALTMANN, 2009, p. 50) e muito menos soluções para a paradoxal relação da sociedade com o ambiente, do qual retira sua manutenção e que, mesmo com essa importância de vida e morte (MILARÉ, 2015), não promove uma identificação responsável com o ambiente.

Essa realidade de crise e de preocupações com o futuro é a característica marcante da realidade. Até que ponto a humanidade já chegou ao nível de irreversibilidade é questão controversa e de secundária importância neste momento. Os riscos são evidentes e seus níveis discutíveis, é verdade, porém, é possível perceber a realidade dentro de um determinado contorno, de certa especificidade em que a inter-relação de fatores políticos, econômicos e ambientais produziram complexas demandas para a sociedade, que não se mostra suficientemente adaptada para esse enfrentamento.

São diversos os fatores de risco produzidos pelas múltiplas crises desenvolvidas nas últimas décadas e que tomaram proporções maiores nos últimos anos, tendendo ao agravamento. Uma população enorme, crescente e concentrada, que consome cada vez mais os bens que o Sistema da Economia produz e transforma luxos em necessidades, acaba criando uma relação de dependência cada vez maior e, com isso, incrementa os riscos do futuro, posto que a escassez de diversos elementos naturais fundamentais é uma realidade preocupante e que afeta diretamente essa dependência. Surge uma realidade paradoxal no tocante à disponibilidade dos recursos e seu preço, na medida em que "devido a possibilidade de esgotamento, o valor dos recursos ambientais tende a crescer no tempo se admitimos que seu uso aumente com o crescimento econômico" (MOTTA, 2006, p. 15).

Esse diagnóstico preocupante é indicativo de uma intrincada ligação entre os diversos fatores de crise relacionados ao meio ambiente. O uso indiscriminado de agrotóxicos e o desmatamento revela a preocupação da comunidade internacional com o desenvolvimento e a manutenção de um ritmo adequado para fazer frente às crescentes necessidades da sociedade. Manter o crescimento ou restringir o mesmo em prol de uma política ambiental são questões que permeiam o debate internacional em torno do tema.

Na mesma linha, a manutenção dos níveis de crescimento e de bem-estar das populações das diversas regiões do globo depende sobremaneira da capacidade de produção de bens e alimentos, processos que dependem essencialmente do acesso à água em proporções e qualidade adequadas, uma vez que a civilização se sustenta sobre dois fundamentos, quais sejam, "nossa capacidade de produzir comida para sustentar um grande número de pessoas que se dedicam a outras tarefas que não o cultivo do alimento. E nossa capacidade de viver em grupos grandes o bastante para prover grandes instituições" (FLANNERY,2007, p. 239).

Em 1962, Rachel Carson ao lançar a obra "Primavera Silenciosa" causou furor na indústria agroquímica ao alertar que os agrotóxicos estavam caminhando para um processo em escalada, em que cada vez mais produtos tóxicos sempre mais letais são lançados para combater pragas resistentes, em que a "guerra química, jamais é vencida, e toda a vida é capturada em seu violento fogo cruzado" (CARSON, 2010, p. 24). Os agroquímicos se acumulam "nos tecidos das plantas e dos animais e chegam a penetrar nas células germinativas para destruir ou alterar o próprio material da hereditariedade do qual depende a forma do futuro". Carson (2010, p. 24) questionava a razão da decisão de correr o risco de ter que pensar que "os seres humanos possam determinar seu futuro 
por meio de algo aparentemente tão trivial quanto a escolha de um inseticida". Ao longo das décadas subsequentes o ser humano deixou a chuva química letal cair sobre ele "como se não houvesse alternativa". Diariamente são colocados agrotóxicos "venenosos e biologicamente potentes indiscriminadamente nas mãos de pessoas ampla ou totalmente ignorantes do seu potencial de danos", submetendo "um grande número de pessoas ao contato com esses venenos sem seu consentimento, e muitas vezes, sem seu conhecimento"(CARSON, 2010, p. 28).

Não há como falar de bem-estar e desenvolvimento sem ter presente a necessidade de uma gestão efetiva da produção de alimentos sustentável, sobretudo para suprir uma população mundial crescente. Dificilmente se alcançará uma mínima justiça distributiva do recurso, sobretudo se baseada apenas na ideia de mercado econômico como fundamento para igualdade de recursos como defende Ronald Dworkin (2005) no contexto da realidade americana. Vive-se em uma sociedade com alto grau de capacidade para transformar o ambiente com base na tecnociência.

Segundo Luhmann (1998), de forma geral se supõe que a sociedade moderna gere, mais que qualquer outra antecessora, mudanças irreversíveis no meio ambiente. E, aqui, a técnica moderna e o mercado orientado à produção industrial são os principais fatores da degradação ambiental, bem como a busca por uma vida cada vez mais longa, o que gera mudanças demográficas impactantes. Para o autor, essa é uma descrição altamente seletiva da sociedade no contexto ecológico, quer dizer, principalmente, na sua dependência do ser vivo Homem.

Portanto, os fatores de risco para a sociedade na atualidade são múltiplos e interligados. A produção de alimentos para uma população crescente e cada vez mais habituada ao consumo e ao conforto trazidos pelo estágio de desenvolvimento que a capacidade de adaptação do ser humano desenvolveu é uma possibilidade muito próxima de ocorrer em diversos níveis. A realidade é paradoxal na medida em que a utilização dos recursos naturais em escalas gigantescas não pode ser sustentada e está acarretando uma grave doença no planeta, qual seja, a degradação (MILARÉ, 2015). Graves problemas ambientais provocados pela ação humana são representativos desse paradoxo. Possivelmente os fatores de risco mais relevantes para a humanidade e a sociedade sejam a falta de identidade com o ambiente e a inadaptação às constantes modificações da realidade.

\section{OS RISCOS ECOLÓGICOS DO DESENVOLVIMENTO DA TECNOCIÊNCIA}

A constatação dos riscos ecológicos do desenvolvimento tecnológico é considerada por Luhmann como o período em que a humanidade finalmente tomou consciência de quão forte a vida humana e o meio ambiente podem ser afetados pelo que o próprio ser humano liberou e pelo que ele mesmo se impôs (LUHMANN, 1991). Por outro lado, Beck (1995) alerta que muitas pessoas públicas respeitadas ainda não se conscientizaram dos riscos resultantes da tecnociência e que o homem pode perder o controle pela tecnologia por estar fascinado pelos seus avanços, e que também não percebe que esta mesma tecnologia pode carregar consigo um potencial destrutivo por não despender a necessária atenção aos efeitos nos alimentos, no ar, nos ecossistemas, na água e na saúde humana.

É neste sentido que para Martínez Garcia (2010) a questão na Sociedade de Risco não é mais eliminar o risco, mas sim ter condições de detectar, configurar ou aprender a manejá-lo. Para o autor, gerir os riscos pode implicar transferi-los, fazê-los repercutir em outros pontos, transformálos, concentrá-los ou distribuí-los, descarregá-los, compensá-los. Trabalhar com riscos ativos exige toda uma dinâmica social. Um modo de produção de riscos, uma tecnologia do risco.

Uma combinação extremamente complexa cujo enfrentamento exige planejamento adaptado a essa realidade, conectado com os diversos elementos formadores dessa realidade de riscos e perigos. Por perigos pode-se delimitar os danos exteriores próprios da ação da natureza, situações que sempre acompanharam a humanidade, os quais se revestem de certa imprevisibilidade, mas que não podem ser atribuídos diretamente ao homem. A possibilidade de 
danos externos são os perigos os quais independem de nossas decisões ou da forma como encaminhamos as demandas da sociedade, sobretudo, as problemáticas ambientais. Cabe ainda uma distinção entre risco e perigo, a qual "supõe (e assim se diferencia precisamente de outras distinções) que existe uma insegurança em relação aos danos futuros". São apresentadas duas possibilidades: i] "o possível dano é uma consequência da decisão, e então fala-se de risco e, mais precisamente, do risco da decisão"; ii] "o possível dano é provocado externamente, ou seja, se atribui ao meio ambiente; e neste caso, fala-se de perigo" (LUHMANN, 1992, p. 65).

Por riscos, têm-se assim as resultantes das decisões (LUHMANN, 1997). Por perigos, tem-se uma possibilidade de dano que foge do controle direto da decisão. Importante ressaltar que, cada vez mais, a influência da ação humana sobre o meio se desenvolve, transformando situações que antes eram aleatórias e independentes de decisões humanas, em realidades complexas em que o risco se destaca, passando dessa forma ao âmbito da decisão, não mais ao aleatório ou, como se poderia chamar, de essencialmente natural que independe da decisão ou da vontade humana. Niklas Luhmann (1992) reforça a noção de que uma mesma ação pode representar risco para um bem como pode representar perigo para outro, surgindo uma clara ligação entre perigo e risco. Segundo o autor a distinção entre risco e perigo se estabelece desde o fato de que os riscos implicam possíveis danos, consequência da própria decisão. Parte do princípio de que a modernidade se abre em função de decisões individuais, de um futuro que, todavia, é incerto e de que esse indivíduo que decide deve assumir a responsabilidade do êxito ou do fracasso. O risco pressupõe a consciência de futuras perdas (LUHMANN, 1997).

Oportuno registrar que, para Schmidt (2007), em defesa do perigo e do risco abaixo do degrau de perigo devem ser utilizadas medidas de prevenção que vêm a ser uma variante de segurança. Em contrapartida, para o autor, o princípio da sustentabilidade está ancorado no fato de poupar recursos de longo prazo e de não utilizar os limites críticos dos recursos.

$\mathrm{Na}$ contemporaneidade, riscos e perigos adquirem alcance global e não mais local, tornando todos indistintamente sujeitos à insegurança do futuro, uma vez que "desde mediados do século XX as instituições sociais da sociedade industrial enfrentam a possibilidade, historicamente sem precedentes, da destruição de toda vida no planeta através das decisões que se tomam" (BECK, 2002, p. 83). A noção de perigo passa para perigos produzidos e imprevisíveis em seu alcance, fugindo ao controle por mecanismos específicos como seguros (BECK, 2002).

A ideia de que a insegurança e a ameaça fazem parte da existência humana gera evidentemente um alerta. Os riscos para Bauman (2008) são como perigos calculáveis. Inclusive para Luhmann (1992, p. 72) "não existe nenhuma conduta libre de riscos". Dessa forma, os seres humanos como promotores de condutas que se repetem e se multiplicam por gerações, estão sempre sujeitos aos riscos da existência, mas, e, sobretudo, aos riscos das decisões acerca de suas condutas.

É preciso lembrar que os riscos globais típicos da sociedade tecnológica e de economia globalizada apresentam-se de formas substancialmente diferentes daqueles riscos típicos da Sociedade Industrial, na qual os riscos revestiam-se de outras características, uma natureza bem mais previsível, controlável e com exigências adaptativas bem menores, na medida em que o conhecimento de sua amplitude e seus desdobramentos era mais presente.

Conforme Ulrich Beck (2002, p.5), risco

é o enfoque moderno da previsão e o controle das consequências futuras da ação humana, as diversas consequências não desejadas da modernização radicalizada. É uma intenção (institucionalizada) de colonizar o futuro, um mapa cognitivo. Toda sociedade, obviamente, já experimentou perigos. Porém o regime do risco é uma função de uma nova ordem: não é nacional, mas sim global. Está intimamente relacionado com o progresso administrativo e técnico da decisão. Anteriormente, essas decisões eram tomadas com normas fixas de cálculo, ligando meios e fins ou causas e efeitos. A 'sociedade de risco global' tem invalidado precisamente essas normas (BECK, 2002, p. 5) 
Na Sociedade Industrial ou na sociedade do passado, essa noção de globalização não existia. Por certo que a expansão marítima e as invenções na área da comunicação como o telégrafo pelo código Morse e depois o rádio de Marconi já davam os contornos do que viria em seguida, mas a perspectiva de um futuro de incertezas não tinha, nem de longe, as características de hoje. Assim, no passado, essa previsibilidade e limitação territorial de possíveis danos provocados pelo homem tinham um alcance muito diferente.

$\mathrm{Na}$ Sociedade de Risco, tudo isso se modifica e a perspectiva passa ser intergeracional e os possíveis efeitos das ações e das decisões transcendem os modelos lineares de causalidade. $\mathrm{O}$ complexo toma o lugar do previsível e ninguém mais está isento ou imune de impactos negativos, mesmo aquelas sociedades bem adaptadas. Exemplo disso é o caso dos danos provocados por dois desastres ambientais que ocorreram nos Estados Unidos no ano de 2018, o furacão Harvey que atingiu o Texas e o Furacão Irma que chegou até a Flórida, revelando, "mais uma vez, que os países de Primeiro Mundo não escapam dos efeitos dos impactos ambientais globais." (PORTOGONÇALVES, 2011, p. 333).

Para Ulrich Beck (1998a), essa possibilidade de alcance global e sem restrições dos danos se assemelha à mecânica do bumerangue, arma que os nativos australianos utilizam há séculos e que serve de metáfora pela trajetória da arma que retorna ao seu arremessador. Dito de outro modo: "Os riscos afetam mais tarde ou mais cedo a quem os produziu ou se beneficiou deles, os riscos mostram na difusão um efeito social de bumerang: nem mesmo os ricos e os poderosos estão seguros". Da mesma forma, Beck (1998a, p.43) referencia que os "efeitos secundários anteriormente latentes também vão de encontro aos centros de produção. Os próprios atores da modernização caem de maneira enfática e muito concreta no ciclo dos perigos, sendo atingidos pelos mesmos".

Com efeito, os riscos alcançam a todos de maneira imprevisível, independentemente da participação da sociedade nos processos de transformação ou na tomada de decisões acerca de como enfrentar as incertezas e indeterminações do futuro. O centro de produção de riscos não tem mais, nessa realidade, isenção ou imunidade frente à complexidade das resultantes da degradação ambiental e das novas tecnologias como a genética, biotecnologia, nuclear e nanotecnologia, por exemplo. Para alcançar esse grau de desenvolvimento o caminho que se segue à vanguarda da tecnociência é produzido a cada passo em frente e tem cada vez mais contornos indefinidos relacionados com o tempo, posto que muitos dos resultados negativos apenas poderão ser vislumbrados depois de ampla propagação e indefinido lapso temporal.

A compreensão da distinção entre risco e perigo é útil para avaliar a complexidade da sociedade contemporânea e para estabelecer categorias de demandas ambientais diferentes com vistas à criação de mecanismos mais efetivos e adaptados à realidade. Porém, necessário se faz compreender a perspectiva ampla da problemática ambiental que cada vez mais se torna interligada, a ponto de surgirem várias regiões de sombra onde se confundem as noções do que é previsível e o que não é, do que é externo, do que é provocado e do que é controlável e programável e do que não é mais possível controlar. Para além da perspectiva de Sociedade de Risco e da diferenciação entre risco e perigo, tem-se que o maior dos riscos (e perigos) que a sociedade mundial enfrenta hoje é especificamente a inadaptação ao risco, ou a incapacidade de identificar o alcance das decisões equivocadas.

Além disso, a incapacidade de perceber as ligações entre os elementos que compõem a complexidade da realidade atual aliada a uma postura de subestimação das consequências que podem decorrer de decisões ambientais equivocadas no presente, sobretudo com a influência econômica, representam uma problemática que exige um direcionamento adequado visando minimizar os efeitos negativos resultantes desse processo. A enorme capacidade de reter, comparar e processar informações científicas nos dias atuais não justifica posturas de encobrimento ou simples negação da realidade. Existe uma realidade posta, concreta e determinável. 


\section{O DIFÍCIL DIÁlogo ENTRE TECNOLOGIA, CIÊNCIA, ECONOMIA E MEIO AMBIENTE}

Os anos noventa marcam a origem da discussão entre os cientistas e a chamada "imprensa popular", em torno dos avanços da modernidade, no seio da sociedade industrial. Goldman (2000) desenvolve que, entre os elementos desse debate, o principal gira em torno da emergência da sociedade do risco ou, como desenvolve Giddens (2000), na transição dos perigos (sociedade industrial) frente ao risco manufaturado (sociedade pós-moderna).

Desde as ciências sociais não é tão simples compreender os riscos como um conceito objetivo, já que em uma mesma situação, um risco pode ser percebido de forma diferente, por diferentes pessoas ou em diferentes contextos. Ainda que se possam enumerar e quantificar as perdas, na hora de avaliar sua importância, os indivíduos (ou grupos) podem considerar outros aspectos de caráter qualitativo. Isso está para além de conhecimento definido pela ciência.

Em princípio, os riscos do meio ambiente caracterizados pela contaminação de agrotóxicos necessitam da interpretação do conhecimento científico para designar a gravidade e para definir os riscos e quem serão os afetados por eles.

Por outro lado, há os que apontam que a ciência não tem respostas para os riscos que se apresentam na modernidade; que inclusive são partícipes de seu crescimento (BECK, 1998a). A discussão em pauta é que os sistemas econômico, político e da ciência não estão conseguindo solucionar os problemas do meio ambiente. Melhor, o que se percebe é que o aporte principal da ciência se encontra no poder de informação e validação dos riscos.

Efetivamente, a ciência sempre esteve associada à ideia de progresso tecnológico. $\mathrm{Na}$ essência, seu objetivo é melhorar as condições de vida do ser humano na terra. Durante muitos séculos nada parecia deter o movimento irreversível e cumulativo da ciência na busca pelo progresso tecnológico. Sua dominação não era contestada, bem como as verdades sobre as quais repousava. Tal domínio agora é questionado e, no lugar da certeza da ciência, a dúvida ocupa o "centro desta representação utópica de um crescimento indefinido da felicidade técnica" (OST, 1997, p. 306). Este processo reflexivo, que inicia na metade do século XX, levou a humanidade a questionar sobre os riscos da tecnociência, do progresso, do desenvolvimento e do crescimento econômico e seus reflexos ao ser humano e ao meio ambiente. Todavia, a reflexão ainda continua antropocêntrica e na convicção da superioridade do ser humano sobre qualquer outra forma de vida.

Por mais defensáveis e louváveis que sejam as promessas da tecnologia moderna elas também se converteram em ameaças (JONAS, 2006, p. 21). E, aqui, cabe destaque para a nuvem de agrotóxico Paraquate que atingiu o pequeno município de Espigão Alto do Iguaçu do estado do Paraná, com 5 mil habitantes, no início do mês de novembro de 2018. O Paraquate é um agrotóxico potencialmente fatal, proibido na Europa desde o ano de 2007, responsável pela intoxicação de 96 moradores da pequena cidade, sendo 50 crianças que eram "alunos de uma escola rural que funciona colada à área agrícola onde o veneno estava sendo aplicado" que apresentaram sintomas que condizem com intoxicação agudo "como fortes dores de cabeça, estômago e barriga, tonturas e vômitos". (FONSECA; MARTINS, 2018). Este é exemplo contundente de que determinados agrotóxicos têm potencial de colocar a própria civilização em risco. Ameaças como a de Espigão Alto do Iguaçu continuam presentes em regiões rurais e urbanas e estão sedimentadas no poder econômico de grandes multinacionais de agroquímicos que se beneficiam pela venda de insumos

Pode-se dizer que entre os riscos que a sociedade se impôs, possivelmente o uso exacerbado de agrotóxicos é o momento histórico recente e conectado à atualidade que melhor sintetiza a arriscada relação que o homem promove com sua intervenção no meio. Com a técnica e a capacidade colossal de ampliar a produção de alimentos foi possível modificar e impulsionar o uso de agroquímicos em benefício de grandes conglomerados multinacionais que, uma vez utilizados, acabariam por provocar outras demandas significativas na produção agrícola desde um nível genético (organismos geneticamente modificados) até a aniquilação de recursos ambientais. 
Como resultado, a função social da ciência começa a ser questionada, bem como os paradigmas que a sustentam.

Esse momento histórico sombrio é emblemático e sintetiza o quão o futuro pode tornar-se incerto e as consequências da ação humana podem ser imprevisíveis. Mesmo não tendo se confirmado o receio coletivo de aniquilação do solo e da água, os riscos, as incertezas quanto ao futuro deveriam ter servido como lições do passado para a sociedade pós-industrial. Infelizmente não foi isso que se verificou. Os avanços tecnológicos no campo, sejam relacionados ao controle de pragas ou ao aumento de produção de alimentos, provocaram a formatação de uma realidade de riscos e incertezas, uma Sociedade de Risco como formulado por Ulrich Beck (2002) em seus escritos anteriores e que, atualizada, se configura como Sociedade de Risco Mundial, mais complexa e paradoxal. Na nova realidade de risco, a influência do homem sobre o meio atingiu níveis nunca antes verificados, expondo sobremaneira "a tremenda vulnerabilidade da natureza a intervenção técnica do homem” (JONAS, 2006, p.32).

Um exemplo recente é a discussão no Brasil sobre a reavaliação de inúmeros agrotóxicos, proibidos em diversos países, como é o caso do Glifosato, que é o ingrediente ativo mais utilizado no Brasil. No ano de 2017 foram comercializados e utilizados no Brasil 173.150, 75 toneladas do ingrediente ativo. Na reavaliação realizada pela ANVISA no início de 2019 a conclusão é de o "Glifosato não apresenta características mutagênicas, teratogênicas e carcinogênicas, não é desregulador endócrino e não é tóxico para a reprodução". Para alicerçar a decisão em favor da continuidade da utilização do Glifosato no Brasil, a ANVISA utilizou estudos científicos e relatórios de agências reguladoras internacionais, buscando assim, indicar que "não há evidências científicas de que o Glifosato cause mais danos a saúde que os testes com animais de laboratório puderam demonstrar". Entretanto, a Anvisa "determinou novos parâmetros de referência para a avaliação de risco do Glifosato, a saber: Ingestão Diária Aceitável (IDA) = 0,5 mg/Kg pc/dia; Dose de Referência Aguda (DRfA) = 0,5 mg/Kg pc/dia; Nível Aceitável de Exposição Ocupacional $(\mathrm{AOEL})=0,1 \mathrm{mg} / \mathrm{Kg} \mathrm{pc} /$ dia”, proibindo, ainda, a sua comercialização para a "jardinagem amadora em dose única, sendo mantida a permissão de comercialização de produtos para jardinagem amadora contendo Glifosato somente na concentração final de 1\%".(ANVISA, 2019a).

O que causa perplexidade no voto da Relatora Alessandra Bastos Soares está em ela reconhecer que as "intoxicações agudas por Glifosato apresentam grande magnitude, mas não causam sequelas. Por outro lado, o coeficiente de letalidade foi alto". Na sequência a Relatora posiciona que a grande maioria dos afetados são "trabalhadores rurais com muito baixo nível de escolaridade" e que a solução seria a adoção de "medidas de mitigação para garantir maior segurança das pessoas que estão em contato com os produtos contendo Glifosato, quais sejam, inclusão de informações de segurança nas bulas" e programas de formação continuada para os aplicadores do produto. (ANVISA, 2019a). Em nenhum momento do voto da Relatora foram observados riscos ao meio ambiente e a responsabilização das empresas fabricantes do ingrediente ativo Glifosato. No dia 01 de agosto de 2019, a ANVISA publicou no Diário Oficial da União nova tabela de reclassificação toxicológica dos agrotóxicos já registrados no Brasil em que o Glifosato sai de extremamente tóxico para uma situação mais branda sendo reclassificado como altamente tóxico (ANVISA, 2019b). Percebe-se, claramente, que o discurso vencedor é dos cientistas das indústrias de agrotóxicos.

A preocupação levantada está no fato da ANVISA/Governo não ter respostas suficientes sobre os danos dos agrotóxicos liberados no contexto da equidade intergeracional e para os ecossistemas. Em nenhum momento falam de riscos ao solo e aos ecossistemas. De igual forma, o Sistema Político quando está a serviço do mercado apresenta dados ancorados em pesquisa cientifica indicando que o uso do agrotóxico liberado irá resultar em mais produtividade e retorno econômico, sem afetar o meio ambiente. Se o Sistema Político e o Sistema da Ciência quando está a serviço do mercado têm lados, então se questiona: quem vencerá essa discussão? 
Certo é que a distinção de um risco objetivo, racional ou real avaliado por cientistas independentes e um risco avaliado por cientistas ligados ao Sistema Econômico e Político é tema que tem gerado polêmica ao longo dos anos e que é essencial para o estudo da percepção e aceitabilidade dos riscos.

Nos primeiros 150 dias do governo brasileiro Bolsonaro foram liberados 199 agrotóxicos para utilização na agricultura pelos órgãos de controle, o que representa mais de um agrotóxico por dia (RUSCHEL, 2019). O mais alarmante está no fato de que $43 \%$ dos pesticidas que foram liberados, foram "proibidos em diversos países, especialmente na União Europeia, um dos principais destinos das exportações do agronegócio brasileiro" (RUSCHEL, 2019). Face ao exposto, questiona-se: o mercado europeu vai continuar comprando produtos alimentícios brasileiros? Como ficará o agronegócio, que é um dos principais "puxadores" do crescimento econômico brasileiro, se o mercado europeu se fechar para produtos com agrotóxicos? Exemplos como a liberação desenfreada de novos agroquímicos, ancorados no "pseudo" sucesso da economia para viabilizar maiores índices de produtividade, têm como aliados a posição do Sistema Político, Sistema Econômico, órgãos de controle como a ANVISA que, em geral, se esquivam de trazer ao grande público discussões aprofundadas sobre o tema ou se posiciona no sentido de apoiar tais teorias.

As razões da economia, da tecnociência e do mercado mundial só avançam sem contradições significativas porque não foram suficientemente questionadas, derrotadas e reavaliadas em seus conceitos de moralidade, estabelecidos em nome dos interesses industriais das grandes empresas fabricantes de agroquímicos que ora dominam os principais setores de tomada de decisões a nível global. O meio ambiente e seus respectivos ecossistemas já sofrerem danos irreversíveis, inobstante haja quem defenda uma possível purificação das águas e solos contaminados. A ciência desenvolvida sob irresponsabilidade não pode reconstruir o que destrói, bem como não há razões compreensíveis para dizer que a ciência recupera o dano que causa enquanto continuar a desenvolver sem limites novas tecnologias e experiências para ampliar a produção de alimentos (BECK, 1995).

Por isso, Beck (1995) conclama a mesma ciência que desenvolveu pesticidas cada vez mais potentes a repensar seus métodos e a clarificá-los para os sistemas político, socioambiental e jurídico. Ou seja, tanto o Sistema Político como o Sistema da Ciência, quando possível, devem deixar claro para os leigos os benefícios e os malefícios de determinado avanço tecnocientífico, no tempo e no espaço. Critica a ciência pela ciência e a corrida dos cientistas para adquirirem o Prêmio Nobel, sem indicar as consequências dos seus inventos ou descobertas. Denuncia que o poder econômico e político, que financia muitas das novas pesquisas na atualidade, não permite divulgar os riscos e perigos dos avanços da ciência e da tecnologia. Portanto, convive-se com pseudoverdades que ficam escondidas sob interesses ainda mais perniciosos, que geram um profundo paradoxo entre ciência moderna e a função da ciência.

Isso implica que a eficiência dos fins da tecnociência permanece vinculada, de alguma maneira, à consciência, à subjetividade e ao arbítrio dos detentores do poder político e econômico. Além disso, Junges (2010, p. 70) argumenta que os "métodos de análise e de intervenção no ambiente natural, processados pela ciência e pela técnica, são inadequados, porque o conhecimento foi dividido em especialidades, fragmentando a natureza pela falta de um saber conjunto". Dito de outro modo: não há uma cultura sistêmica no sistema da ciência (bem como de outros sistemas) que analisa os efeitos de determinado avanço científico na natureza em conjunto.

Essa vulnerabilidade do meio à ação humana é, cada vez mais, uma fonte de riscos para a manutenção de níveis de desenvolvimento e dependência do homem, que criou uma Sociedade de Risco (global) que distribui de forma desigual esses riscos (BECK, 1998b). Essa desigualdade na distribuição dos riscos provoca tensões e situações de conflito na medida em que nem todas as sociedades estão preparadas para enfrentar da mesma maneira a realidade, ou seja, sua capacidade de adaptação às resultantes negativas da intervenção no meio não são iguais. 
Possivelmente em alguns aspectos a ciência não consiga ainda abarcar toda a complexidade das interligações que existem entre os processos naturais e a ação humana, porém, já é possível avaliar com grande precisão um considerável rol de fatores de riscos aos quais a humanidade está submetida, até porque a sociedade se caracteriza pelas inúmeras possibilidades de escolhas e, assim, pela hipercomplexidade (ROCHA; KING; SCHWARTZ, 2009), o que dificulta o desenvolvimento e implementação de mecanismos aptos (adaptados). Essas avaliações implicam em conhecimento o mais amplo possível e aceitação da realidade que esse conhecimento revela. Ao conhecer e aceitar a realidade dá-se um passo importante no sentido de reconhecer os riscos e aceitar sua relevância. Não uma aceitação no sentido de conformidade, mas um reconhecimento claro da realidade que possa proporcionar as condições, o ambiente para uma atuação adaptativa efetiva.

Por tudo isso, Jonas (2006, p. 22) argumenta que a "aventura tecnológica impõe, com seus riscos extremos, o risco da reflexão extrema", mas também alerta que não se pode perder esse "dever recém-surgido", expresso no que ele conceitua de responsabilidade. Ao elaborar seu "tractatus technologico-ethicus", Jonas (2006) diz que o perigo não está em saber o que o homem ainda é capaz de fazer, mas sim o quanto a natureza é capaz de suportar e para isso a ciência atual ainda não tem condições de responder e oferecer resultados seguros. Não está a condenar e a desestimular os avanços do progresso técnico, mas sim a fazer um alerta sobre o perigo desses poderes caírem em mãos erradas e a convocar a ciência para lidar com a enorme complexidade das interdependências de seus avanços. E é nesse contexto que se estimula a prudência como coragem e o imperativo "coragem para assumir a responsabilidade" (JONAS, 2006, p. 351).

Na sequência, será apresentado um estudo de caso relacionado com a percepção de riscos (ou a falta de) pela fala de diferentes atores e como estes percebem ou como se relacionam sobre os efeitos da deriva do herbicida 2,4-D, que é apontado como causa de grandes prejuízos pelos produtores de uvas do estado do Rio Grande do Sul.

\section{A PERCEPÇÃO DE RISCO DA DERIVA DO HERBICIDA 2,4-D E AS PRIMEIRAS AÇÕES NO ESTADO DO RIO GRANDE DO SUL}

O regime de risco tornou-se realidade na sociedade produtiva com a transferência dos riscos dos fabricantes de produtos, os que utilizam os produtos em seus processos produtivos e os consumidores, ocasionando um silencioso abismo em toda a cadeia de produção até o consumo e a destinação final. Dependendo da região, os agricultores, trabalhadores rurais e consumidores estão cada vez mais à margem da sociedade ou criam a sua própria sociedade divorciada da realidade por estarem numa dependência localizada pelo efeito da globalização (BECK, 2003). Ou seja, não é apenas em sentido amplo que se pode avaliar a problemática do risco e da tecnologia no contexto de economia globalizada. Exemplificando a questão, tem-se uma realidade muito peculiar no uso do herbicida 2,4-D no sul do Brasil.

O 2,4-D ou ácido diclorofenoxiacético é um dos herbicidas que marca o início da indústria química datando de 1941 e, desde lá, é utilizado em larga escala, em especial nas culturas de soja, trigo e milho, com objetivos de controlar plantas infestantes para obtenção de rendimentos mais elevados na produção agrícola (INACIO, 2016). Entretanto, o produto apresenta inúmeros problemas à agricultura moderna, entre os quais destaca-se a possibilidade de causar deriva, o que pode resultar em perdas qualitativas e quantitativas na produção de culturas sensíveis, como na produção de uvas, maçãs e oliveiras. Deriva é definida "como o movimento de poeira ou gotículas do produto aplicado através do ar para áreas não previstas no momento da aplicação" podendo causar graves danos "na produtividade e morfologia das culturas sensíveis". Os resíduos do herbicida 2,4-D ficam na atmosfera e são levados pelo vento ou chuvas para campos vizinhos de produção, "em concentrações suficientes para causar danos significativos a culturas sensíveis" interferindo no seu desenvolvimento e podendo levar à morte estes cultivares. A lesão pela deriva 
geralmente ocorre no "início do desenvolvimento das plantas suscetíveis, ou quando as plantas estão no início da fase de crescimento reprodutivo" (INACIO, 2016, p. 12).

A Association Of American Pesticide Control Officiais (APPCO) relata que em 2004 "o herbicida 2,4-D foi o ingrediente ativo que obteve o maior número de ocorrências de deriva" nos Estados Unidos (INACIO, 2016, p. 12). Se o produto não é aplicado corretamente e se for aplicado em doses mais elevadas pode ocasionar escorrimento e exoderiva atingindo culturas sensíveis a este agrotóxico. Razão pela qual são necessários estudos científicos continuados para, além "de estudar fatores inerentes às plantas infestantes a serem controladas" também sejam estudados fatores inerentes à aplicação, como o tamanho e a densidade de gotas, as perdas para o solo e por deriva, o equipamento pulverizador, o volume de calda e as pontas de pulverização" (SOUZA; CUNHA; PAVANIN, 2012).

Para ter uma ideia do seu uso, no Brasil o 2,4-D é o segundo agrotóxico mais utilizando, sendo que só no ano de 2017 foram aplicadas 60 mil toneladas do herbicida que é produzido por 24 empresas e com 71 marcas diferentes, que em sua composição contêm essa substância. O 2,4D fica apenas atrás do glifosato (O GLOBO, 2019). Nos últimos 40 anos o uso de agrotóxicos com a substância ativa 2,4-D ampliou 700\% a nível mundial e esse aumento tem relação direta com o desenvolvimento de culturas transgênicas de soja, milho e algodão, visto que o 2,4-D pode "ser aplicado em diferentes estádios fenomenológicos destas culturas", tornando-se extremamente atraente para ampliar a produtividade (INACIO, 2016, p. 12-16).

Além dos danos à deriva em plantas sensíveis, o 2,4-D tem sido documentado por várias pesquisas como um produto com graves efeitos tóxicos à saúde humana, sendo "classificado pela União Europeia (UE) como uma substância de desregulação endócrina ou potencial de desregulação endócrina comprovada". Seu uso indiscriminado ampliou a poluição do solo, águas e alimentos, o que tem levado ao aumento de identificação de doenças respiratórias, risco sanitário para o abastecimento público de água, toxicidade e persistência no meio ambiente (COELHO; LEAL; SOUZA; ROZÁRIO; ANTUNES, 2018).

No caso do herbicida 2,4-D há um conflito instalado entre produtores de culturas mais sensíveis com produtores de soja, que deixou de ser silencioso quando atingiu a safra de uvas, maçãs, citrus, erva-mate, mel, azeitona, sementes de hortaliças e outras culturas de agricultores do estado do Rio Grande do Sul, com perdas milionárias acumuladas na safra da uva, para ser pauta de discussões entre o Poder Judiciário (Ministério Público); Poder Executivo (Secretarias Estaduais da Agricultura, Meio Ambiente e Saúde); Poder Legislativo (comissões de Agricultura, Meio Ambiente e Saúde), Associação dos Vinhos da Campanha, Instituto do Vinho Brasileiro (IBRAVIN), FECOVINHO, FARSUL, AGAPOMI, produtores rurais e empresas fabricantes do princípio ativo 2,4-D agrotóxico.

No início de 2019, o Instituto Brasileiro do Vinho (IBRAVIN) encaminhou ao Ministério Público do estado do Rio Grande do Sul, um estudo que demonstra "os prejuízos causados pelo herbicida 2,4-D à produção vitivinícola do Estado". Para exemplificar, a redução da safra de uvas 2017/2018 foi de 32\% com prejuízos estimados em R \$ 100 milhões em 2018. O relatório aponta que a redução da safra e os prejuízos estão diretamente vinculados aos danos decorrentes da deriva da aplicação do herbicida nas lavouras, em especial da soja, da região. (IBRAVIN, 2019).

O conflito durante um longo período foi silencioso, ao tempo que as grandes multinacionais de agrotóxicos negavam e ainda negam os riscos para a saúde humana e meio ambiente; sequer aceitam que este é um conhecimento construído com evidências científicas sobre os riscos ambientais futuros, à saúde laboral e à saúde do consumidor de produtos com agrotóxicos, um conhecimento adquirido na "escola da vida", parte do que Goffman (1993) expõe das interações do cotidiano, o cara a cara e os efeitos vivenciados por intoxicação e doenças de familiares e de pessoas próximas ou perdas na produção pelos efeitos da deriva. Talvez esteja aí o grande problema da relação entre os sistemas econômico, político, científico e socioambiental: o discurso não necessita ser técnico científico para ser conhecimento; a significação do conhecimento cotidiano, 
adquirido pelos produtores de culturas afetadas pelo uso do herbicida 2,4-D exigiu que o Ministério Público, Governo do estado do Rio Grande do Sul, indústrias fabricantes do agrotóxico e ciência apresentassem respostas e soluções ao problema enfrentado. Trata-se aí de perceber o que Goffman (1993) desenvolve dos marcos de significados ou da chamada consciência prática, já pontuada por Giddens (1995). Este conflito não é apenas no estado do Rio Grande do Sul sendo pauta de discussão em vários Estados brasileiros com cultivares sensíveis.

No caso específico do estado do Rio Grande do Sul, o conflito sobre os efeitos da deriva ocasionada pela aplicação do herbicida 2,4-D, em especial em lavouras de soja, se dá entre porteiras, ou seja, de um lado os produtores de soja, a principal cultura gaúcha e brasileira, que na safra 2018/2019 produziram somente neste estado aproximadamente 18,545 milhões de toneladas e, do outro lado, os produtores de uvas, historicamente muito vinculados à cultura gaúcha, que alcançaram em 2018 um volume de 664,2 mil toneladas colhidas (RIO GRANDE DO SUL, 2019a). Nos últimos dois anos os vinhedos e pomares de oliveiras nas regiões da Campanha, Novos Campos de Cima da Serra, Fronteira e Centro, vêm alertando o governo do Estado sobre perdas expressivas relacionadas com a deriva do 2,4-D. No final do ano de 2018, pela primeira vez, os atingidos conseguiram comprovar a presença do princípio ativo 2,4-D nas plantas afetadas. Por solicitação dos produtores, a Secretaria da Agricultura analisou 53 amostras em 18 municípios e comprovou com laudos que 52 análises deram positivo, atingindo 47 propriedades. O Inquérito Civil foi aberto pelo Ministério Público em 2015. (ROLLSING, Carlos; SOARES, Fernando; COLUSSI, Joana, 2018).

A interpretação e a percepção dos atores sobre os riscos é um fenômeno que poderá trazer novas configurações quando o sistema econômico atingir o próprio sistema econômico (de um lado indústria de agroquímicos e produtores de soja e do outro lado produtores de culturas mais sensíveis), que a sua vez, tem influência direta no contexto coletivo de um Estado ou comunidade. Perceber o risco e aceitá-lo depende, em muito, do quanto esse risco pode afetar determinado setor econômico e, posteriormente, são observados riscos ao meio ambiente e à saúde humana, sobretudo quando se fala em agrotóxicos, em grandes países produtores de alimentos e indústrias de insumos. Até o ano de 2016, os efeitos da deriva do herbicida 2,4-D foram menos significativos para os produtores de culturas sensíveis, mas com o uso continuado, ampliado e, muitas vezes, incorreto de aplicação, os danos ocasionados mostraram-se visíveis e atingiram sensível redução na colheita de uvas, o que resulta em prejuízo econômico para o setor. Na sequência serão transcritas uma série de reportagens e entrevistas realizadas pela imprensa brasileira com diferentes atores envolvidos no conflito da deriva do 2,4-D, e que serve para complementação e análise da relação produtores de soja e produtores de uvas.

Em 11 de fevereiro de 2019, o Diário Oficial da Assembleia Legislativa do estado do Rio Grande do Sul divulgou a solicitação de desarquivamento do Projeto de Lei n. 262/2014 de autoria do Deputado Edgar Pretto que dispõe sobre a proibição a fabricação, uso e comercialização de agrotóxico que contenha em sua fórmula o ingrediente ativo 2,4-D em todo o território gaúcho. No Projeto de Lei n. 262/2014, que novamente volta ao debate após seu autor solicitar o desarquivamento, pauta a justificativa da proibição no alerta de que o 2,4-D "é questionado em vários países e segundo o Parecer Técnico do GEA, o produto é proibido na Dinamarca, Suécia e Noruega". Nas considerações que embasam a necessidade de proibição é apontado que:

Em 2014, o Ministério do Desenvolvimento Agrário (MDA) através do Núcleo de Estudos Agrários e Desenvolvimento Rural (NEAD) encaminhou a ANVISA um Parecer Técnico sobre o 2,4-D elaborado pelo Grupo de Estudos em Agrobidiversidade (GEA) que entre outras conclusões afirma "Há informação científica suficiente para comprovar que o 2,4-D pode ser incluído nas categorias de produto genotóxico, toxidade do sistema reprodutivo, neurotóxico e desregulador endócrino". O 2,4-D tem como característica a tendência de se espalhar no ar mais do que a maioria dos herbicidas, podendo atingir pomares e 
outros cultivos localizados nas proximidades das lavouras onde é aplicado este herbicida, bem como áreas residenciais. Tem causado fitotoxidade em plantas como videiras, gerando problemas socioeconômicos em comunidades rurais. Estudos indicam que o produto é tóxico para macro e microrganismos benéficos à fertilidade dos solos, afetando também predadores naturais causando desequilíbrios ecológicos. (PRETTO, 2019)

Observa-se que o representante da Associação dos Vinhos da Campanha, Valter Pötter, em entrevista realizada para Colussi (2019) confirma as características do herbicida 2,4-D apontado pelo Ministério do Meio Ambiente em 2014, como exposto, na PL n. 262/2014 e, ainda, alerta que o problema da deriva nas plantações de uvas é "maior que os laudos oficiais confirmam". Para subscrever seu alerta, Pötter demonstrou que entre os problemas que causam a deriva, estão as condições meteorológicas adversas na região da Campanha na primavera, quando é aplicado o 2,4D nas lavouras de soja, período este em que não são obedecidas a velocidade dos ventos indicada na recomendação técnica do produto, que deve ficar entre $2 \mathrm{~km} / \mathrm{h}$ e $10 \mathrm{~km} / \mathrm{h}$. Pötter justifica dizendo que no "mês, são seis ou sete dias com velocidade média abaixo de 10 quilômetros por hora. Essa situação vai liquidar com a diversificação no Estado" (COLUSSI, 2019).

Em outra reportagem realizada por Rollsing, Soares e Colussi (2018, p.3) foi divulgada uma entrevista realizada com João Minuzzi, presidente da Cooperativa Agrária São José, fabricante dos vinhos Jaguari, situado em um dos municípios que sofreu com a deriva do herbicida 2,4-D, em que o presidente argumenta que "alguns produtores arrancaram os parreirais. Não somos contra a soja, mas precisamos sobreviver". Neste sentido, o Presidente da Federação da Agricultura do Rio Grande do Sul (FARSUL) apresenta uma solução simplista ao dizer que "o conflito existe e deve ser resolvido com treinamento. Proibição não é a solução" (ROLLSING; SOARES; COLUSSI, 2018, p. 3). Na mesma linha, Robinson Osipe, professor de Agroecologia da Universidade Estadual do Norte do PR falou que "qualquer produto que for aplicado incorretamente causará danos, não é uma característica específica do 2,4-D. A questão não é proibir, mas a penalização de quem usa indevidamente" (COLUSSI, 2019).

Para minimizar o conflito entre produtores de uvas e produtores de soja, a Secretaria da Agricultura, Pecuária e Desenvolvimento Rural do estado do Rio Grande do Sul em com conjunto com entidades participantes do grupo de trabalho criado para discutir o tema, elaborou e publicou duas Instruções Normativas para minimizar o problema da deriva. A Instrução Normativa 05/2019 "estabelece o Termo de Conhecimento de Risco e de Responsabilidade, pelo qual o produtor rural ou representante legalmente habilitado deverá assinar a receita agronômica". Ao assinar o termo, tanto o produtor rural como o técnico que assinará a receita agronômica, reconhecem que estão cientes de "os produtos agrotóxicos hormonais, inclusive os produtos com ingrediente ativo à base de ácido 2,4-diclorofenoxiacético (2,4-D), em caso de deriva, causam grandes prejuízos para as culturas sensíveis". Por sua vez, a Instrução Normativa de n. 06/2019 criou a figura do aplicador do produto que deverá se cadastrar para desempenhar a função, bem como realizar treinamento para aplicar o produto. Portanto, esta a Instrução Normativa 06/2019 criou "regras para o cadastro dos aplicadores de produtos agrotóxicos hormonais e a necessidade do produtor prestar informações sobre o uso do produto" (RIO GRANDE DO SUL, 2019b).

A Associação de Vinhos da Campanha e outros setores ligados à produção de uvas no Estado do Rio Grande do Sul criticaram as medidas, em especial, que não são exigidas informações importantes sobre as formas e equipamentos indispensáveis para aplicar o produto e evitar a deriva, prazo estipulado de 10 dias para que o aplicador comunique que está aplicando o herbicida 2,4-D muito longo, visto que neste intervalo, "os vestígios de eventual má aplicação já terão desaparecido" e, principalmente, questionam "por que as revendas não precisam assinar o documento?" (LOEBLEIN, 2019, p. 17).

Percebe-se que novamente o Sistema Político não responsabiliza um dos atores do Sistema Econômico, que neste caso, são as grandes empresas multinacionais de agrotóxicos. Claro está que

Revista de Direito Brasileira | Florianólopis, SC | v. 25 | n. 10 | p. 120-141 | Jan./Abr. 2020 
o produtor rural de soja que aplica o herbicida 2,4-D tem responsabilidade pela aplicação, mas a industrial de agrotóxicos tem responsabilidade pelos produtos que coloca no mercado. Nesta linha, questiona-se: há uma democratização da contaminação por parte da empresa de agrotóxicos? Antes de qualquer juízo de valor, analisa-se aqui a capacidade de formulação cognitiva de inúmeros produtores rurais sobre a dimensão de um risco. Tratando-se de indústrias de agrotóxicos comungase da ideia de que são empresas autorizadas a comercializarem seus produtos pela administração pública, pelas instituições ambientais. O produtor de soja deverá assumir a responsabilidade individualmente e o produtor de culturas sensíveis os riscos da deriva? Capacitação do aplicador resolve o conflito instalado entre produtores de soja e produtores de uvas?

As indústrias de agroquímicos não estão sendo responsabilizadas pelo dano ambiental futuro e pelos riscos à saúde humana e meio ambiente. O que Beck (1998a) chama complexidade da problemática do risco e que a sociedade deve estar constantemente refletindo sobre suas elegibilidades não é compatível com essa realidade. O contexto das empresas de agroquímicos estão sustentadas por outros elementos construídos socialmente, que são mais importantes que a contaminação ou problemas ambientais, como segurança do trabalhador rural, segurança alimentar, segurança das culturas vizinhas, degradação do solo, poluição do ar e dos recursos hídricos.

Determina-se assim que a capacidade de vigiar e proteger-se diante de fatores indesejados do risco dos agrotóxicos ao meio ambiente e à saúde humana ainda é embrionário e altamente voltado aos interesses das indústrias que os produzem. Douglas (1982) e Wildawsky (1990) fazem uma crítica à dificuldade da aceitação do risco objetivo e subjetivo. Para os autores não há coerência em maximizar ganhos ou minimizar perdas, tanto que os perigos não são dados absolutos para uma seleção racional. Entretanto, o aumento exponencial no uso de agrotóxicos, no Brasil e no mundo, mostra que há uma construção social dos riscos, que são moralizados e politizados; razão de uma cultura do risco associada ao poder econômico e político, onde os perigos são minimizados através de um filtro cultural.

A aceitabilidade do risco pelo uso de agrotóxicos está também relacionada com a questão política, pois o que se define como um risco para a ciência, ainda pode ser valorizado pelos leigos e admitido como risco; porém, a necessidade de ampliar a produtividade agrícola faz que se aceite determinado risco em detrimento de outro.

Outro fator que se manifesta na realidade da deriva do 2,4-D é um conflito interno nos sistemas econômicos, políticos e socioambiental que pode levar ao descrédito da sociedade. Os sistemas de peritos formulam suas teorias em defesa da instituição que contratam seus serviços, mais pela "verdade investigativa". O caso se revela nas revalidações de determinados agrotóxicos pela ANVISA e nas pesquisas de pesquisadores vinculados à Instituições de Ensino publicadas em periódicos científicos internacionais: a primeiro informa apoiada também pela ciência que o agrotóxico objeto de revalidação não tem comprovação científica de que causa determinadas doenças; a segunda informa que o mesmo agrotóxico apresenta características carcinogênicas, mutagênicas, teratogênicas, que é desregulador endócrino e que é tóxico para a reprodução.

Não se nega a importância dos resultados da revalidação de agrotóxicos, porém, os conflitos ou omissões de resultados fidedignos (como no caso citado) levam o conhecimento divulgado pelo Sistema Político à perda de legitimidade. De igual forma, tem-se presente que os laudos da Secretaria de Agricultura do Estado do Rio Grande do Sul apontaram que das 81 amostras de solo analisadas nas plantações de uvas, 69 mostraram resíduos do herbicida 2,4-D. Os resultados apontam que o conflito instalado neste Estado está também ocorrendo em outros e há um enorme risco em relação a diversificação de culturas. Talvez este não chegue a ser um questionamento dos agricultores e trabalhadores rurais que utilizam o herbicida 2,4-D nas lavouras de soja, da própria academia originária dos sistemas da ciência, que se encontram temerosas pela negligência investigativa a favor de interesses particulares, institucionais e, sobretudo, econômicos. A questão é conflitiva e sem diminuir a gravidade dos fatos pode-se questionar: até que ponto um 
produtor/trabalhador rural (sem nenhuma o com baixa escolarização) tem a responsabilidade pelo risco?

O conhecimento que tem o produtor de uvas e culturas sensíveis é legitimo quando observam suas culturas definhando e o solo contaminado? E o conhecimento do produtor de soja? A maioria dos produtores agrícolas nega o risco porque o construíram no desenvolvimento sociocultural desta sociedade que, todavia, vive sobre a influência da primeira modernidade (sociedade industrial). Em contrapartida, o que se pode dizer do sistema político, econômico, científico, jurídico e socioambiental, amparados pela ética, que negam ou omitem a verdade? $\mathrm{O}$ que é mais grave: a negação verdadeira (no caso em estudo dos produtores de soja) ou a omissão irresponsável dos Sistema Político e das industrias de agrotóxicos?

Enfim, não se tenta generalizar o conflito instalado entre fronteiras no estado do Rio Grande do Sul de "ingenuidade" dos produtores de soja ou de "insensatez" por parte das indústrias de agroquímicos e da área política que os libera; mas sim como referência para (re)pensar os riscos e como responsabilizar o fabricante de agrotóxicos. Tanto a política com a ciência não pode estar a serviço de interesses econômicos; e sim em conformidade e compromisso com a verdade.

\section{CONCLUSÃO}

No que tange ao uso de agrotóxicos, sem dúvidas, os mesmos foram desenvolvidos para ampliar a produtividade do campo, principalmente em nome da necessidade de ampliação de alimentos para dar conta do aumento populacional no período pós Segunda Guerra Mundial. O ceticismo prevaleceu por muito tempo e a dominação dos agrotóxicos e o aumento da produtividade eram incontestáveis. Porém, nas últimas décadas os riscos dos agrotóxicos são denunciados pela relação direta com doenças carcinogênicas, mutagênicas, teratogênicas, carcinogênicas, desregulador endócrino e toxicidade para a reprodução, além de denúncias sobre o extermínio de abelhas, danos às culturas sensíveis, poluição do ar, do solo e dos recursos hídricos. Estas denúncias demonstram que o predomínio da utilização de agrotóxicos como única alternativa para ampliar a produção de alimentos passa a ser questionado, e as certezas dão lugar às incertezas; e a humanidade passa a questionar determinadas técnicas certificadas pela ciência, que tem levado a um progresso e crescimento, sem responsabilidade com a vida do planeta terra. Como visto, desde a denúncia de Rachel Carson em 1962 sobre o DTD na obra Primavera Silenciosa, passando pelo exemplo brasileiro de reavaliação de agrotóxicos como o Glifosato e o conflito instalado entre porteiras no estado do Rio Grande do Sul a indústria milionária de agrotóxicos passa, de certa forma, a estar a serviço do poder econômico e político e, com isso, a exigência de responsabilidade por danos futuros é questionada e exigida.

A humanidade evoluiu significativamente pela tecnociência. Porém, juntamente, os paradoxos e as incertezas do futuro aumentam e a ação humana torna-se cada vez mais imprevisível. Beck e Giddens dimensionam essa discussão na emblemática sociedade de risco e, para, além disso, esses autores criticam o desenvolvimento da ciência pela ciência, cobrando clareza de seus benefícios e malefícios para a população leiga, principalmente o compromisso na divulgação dos riscos e perigos dos avanços oriundos da ciência.

Ainda, na mesma direção, nesta sociedade, "a mão nem sempre é orientada pela cabeça"; ou seja, os princípios individuais não são suficientes para gerar atitudes que promovam um ambiente saudável. A influência macroeconômica limita e, de certa forma, impõe que decisões como a de não responsabilizar o fabricante do herbicida 2,4-D pelos danos a deriva nas culturas sensíveis se aceite; a exigência posta pelo mercado não é uma exigência moral, mas sim, é institucionalizada e amparada pela legislação. Demonstrar que os agrotóxicos causam riscos transtemporais, transgeracionais e invisíveis deveria ser suficiente para dizer não a uma indústria que contamina o solo, o ar e as águas. Há uma distância entre o dano aceitável, os riscos para as gerações presentes e futuras e a responsabilização pelo dano futuro. 
O conflito se expande quando esta aproximação (legal-moral) chega ao segmento das grandes indústrias agroquímicas. Com relação às questões ambientais, as indústrias estão amparadas pela lei, ou seja, a comercialização e aplicação de seus produtos foram aprovadas e seguem as exigências legais; deste modo, os produtores de soja que utilizam o 2,4-D exemplificado no texto - é a principal cultura e referência de produtividade agrícola e participação no PIB nacional. A controversa é que os produtores de uvas e de outras culturas sensíveis foram afetados com prejuízos milionários e provaram que o agrotóxico 2,4-D utilizado no plantio de soja para eliminar ervas daninhas está afetando as plantações de uvas, maçãs e oliveiras pela deriva. Entretanto, as primeiras ações tomadas pelo Sistema Político remetem apenas ao aplicador do produto nas lavouras de sojas, enquanto, para a grande indústria produtora de agrotóxicos não recai nenhuma ação. A esperança está no dizer de Beck (1998a, p. 43): "os riscos afetam mais tarde ou mais cedo a quem os produziu ou se beneficiou deles".

Por fim, o uso de agrotóxicos, que no passado gerava confiança pelo aumento de produtividade, hoje também gera insegurança. E a descrença da população aumenta quando, diante de um mesmo fato, os laudos técnicos científicos expressam redações diferentes; sobretudo quando esse laudo defende ou inocenta a grande indústria multinacional de agrotóxicos na qual o produto é fabricado. Sem juízo de valor, cabe terminar com o questionamento já feito por Giddens: a quem a ciência e a política está a serviço? Da verdade ou do capital econômico?

\section{REFERÊNCIAS}

ALTMANN, Alexandre. O desenvolvimento sustentável e os serviços ambientais In: RECH, Adir Urbano.; ALTMANN, Alexandre. (Orgs.). Pagamento por serviços ambientais: imperativos jurídicos e ecológicos para a preservação e restauração das matas ciliares. Caxias do Sul: Educs. 2009.

AGÊNCIA NACIONAL DE VIGILÃNCIA SANITÁRIA - ANVISA. 2019a. Voto no 016/2019/2019/SEI/DIRE2/ANVISA. Rop 006/2019 Item 2.2.1. Processo $n^{\circ}$ 25351.056754/2013-17. Relatora Alessandra Bastos Soares. Data do voto: 26 jun. 2019.

AGÊNCIA NACIONAL DE VIGILÃNCIA SANITÁRIA - ANVISA. 2019b. Publicada reclassificação toxicológica de agrotóxicos. 01 ago. 2019. Disponível em: $<$ http://portal.anvisa.gov.br/noticias/-/asset_publisher/FXrpx9qY7FbU/content/publicadareclassificacao-toxicologica-de-agrotoxicos-

/219201?p_p_auth=L13h8LiD\&inheritRedirect=false\&redirect=http\%3A\%2F\%2Fportal.anvisa.g ov.br\%2Fnoticias\%3Fp_p_auth\%3DL13h8LiD\%26p_p_id\%3D101_INSTANCE_FXrpx9qY7Fb U\%26p_p_lifecycle\%3D0\%26p_p_state\%3Dnormal\%26p_p_mode\%3Dview\%26p_p_col_id\%3 Dcolumn-4\%26p_p_col_count\%3D6>. Acesso em: 09 ago. 2019.

ANVISA mantém liberado segundo agrotóxico mais vendido no Brasil, mesmo com risco a trabalhadores rurais. O Globo. Publicado em: 14 maio 2019. Disponível em: <https://oglobo.globo.com/sociedade/anvisa-mantem-liberado-segundo-agrotoxico-maisvendido-no-brasil-mesmo-com-risco-trabalhadores-rurais-23664772 >. Acesso em: 03 ago. 2019.

BAUMAN, Zygmunt. Modernidade líquida. Rio de Janeiro: Jorge Zahar, 2001.

BAUMAN, Zygmunt. Medo líquido. Traduzido por Carlos Alberto Medeiros. Rio de Janeiro: Zahar, 2008.

BECK, Ulrich. Ecological Enlightenment. New York: Humanity Books, 1995. 
BECK, Ulrich. La sociedad del riesgo. Barcelona: Paidós Ibérica, 1998a.

BECK, Ulrich. Políticas ecológicas en la edad del riesgo- Antídotos la irresponsabilidad organizada. Barcelona: Editorial el Roure, 1998b.

BECK, Ulrich. La sociedad del riesgo global. Madrid: Siglo XXI de España, 2002.

BECK, Ulrich. Liberdade ou Capitalismo. São Paulo: Editora UNESP, 2003.

BECK, Ulrich. La sociedad del riesgo mundial: en busca de la seguridad perdida. Barcelona: Paidós Ibérica, 2008.

COELHO, Edumar Ramos Cabral; LEAL, Waldiléia Pereira; SOUZA, Karoline Barros de; ROZÁRIO, Andréia; ANTUNES, Paulo Wagnner Pereira. Desenvolvimento e validação de método analítico para análise de 2,4-D, 2,4-DCP e 2,4,5-T para monitoramento em água de abastecimento público. Eng. Sanit. Ambient. Rio de Janeiro, v.23, n.6, nov./dec. 2018. Disponível em: <http://www.scielo.br/scielo.php?script=sci_arttext\&pid=S141341522018000601043>. Acesso em: 03 ago. 2019.

COLUSSI, Joana. Comissões parlamentares pedem suspensão do uso do herbicida 2,4-D no RS. GAÚCHAZH, Campo e Lavoura, Porto Alegre, 8 maio 2019. Disponível em: $<$ https://gauchazh.clicrbs.com.br/economia/campo-e-lavoura/noticia/2019/05/comissoesparlamentares-pedem-suspensao-do-uso-do-herbicida-24-d-no-rscjvfjqchp024w01mawdjpor1r.html >. Acesso em: 03 ago. 2019.

DOUGLAS, Mary. How institutions think. New York: Syracuse University Press, 1986.

DOUGLAS, Mary.; WILDAVSKI, A. Risk and culture: an essay on the selection of technical and environmental dangers. Berkeley, Los Angeles: Univ. of California Press, 1982.

DWORKIN, Ronald. A virtude soberana: a teoria e a prática da igualdade. Traduzido por Jussara Simões. São Paulo: Martins Fontes, 2005.

EFKEN, Karl Heinz. A ciência e a conscientização a serviço dos recursos hídricos: a água como fonte de comunicação biológica global. In: PETERS, T. P. S. et al. Água: fonte de vida. Recife: UNICAP, 2005.

FLANNERY, Tim. Os senhores do clima. Traduzido por Jorge Calife. Rio de Janeiro: Record, 2007.

FONSECA, Bruno; MARTINS, Rafael Moro. Contaminação recorde por agrotóxicos no Paraná atinge mais de 50 crianças. Pública: Agência de Jornalismo Investigativo. 11 dez. 2018.

Disponível em: < https://apublica.org/2018/12/contaminacao-recorde-por-agrotoxicos-no-paranaatinge-mais-de-50-criancas/ > . Acesso em: 08 ago. 2019.

GIDDENS, Anthony. Modernidad e identidad del yo: el yo y la sociedad en la época contemporânea. Barcelona: Península, 1995.

GIDDENS, Anthony. O mundo na era globalizada. Lisboa: Presença, 2000. 
GOFFMAN, Erving. La presentación de la persona en la vida cotidiana. Buenos Aires: Amorrortu, 1993.

GOLDMAN, Laurence R. Social Impact Assessment. Berg: Oxford England, 2000.

INSTITUTO BRASILEIRO DO VINHO (IBRAVIN). Ministério Público recebe documento com prejuízos causados pelo 2,4-D à vitivinicultura gaúcha. Publicado em: 12 abr. 2019. Disponível em: <https://www.ibravin.org.br/Noticia/ministerio-publico-recebe-documento-comprejuizos-causados-pelo-2-4-d-a-vitivinicultura-gaucha/417>. Acesso em: 04 jun. 2019.

JONAS, Hans. O Princípio Responsabilidade: em busca de uma ética para a civilização tecnológica. Traduzido por Marijane Lisboa e Luiz Barros Montez. Rio de Janeiro: Contraponto, Ed. PUC-Rio, 2006.

JUNGES, José Roque. (Bio)Ética Ambiental. São Leopoldo, EdUNISINOS, 2010.

LOEBLEIN, Gisele. A Fiscalização das novas regras do 2,4-D. Zero Hora, Campo Aberto, publicado em 08. Jul. 2019.

LUHMANN, Niklas. Soziologie des risikos. Berlin, New York: De Gruyter, 1991.

LUHMANN, Niklas. Sociologia del riesgo. Guadalajara: Universidad Iberoamericana, Universidad de Guadalajara, 1992,

LUHMANN, Niklas. Observaciones de la modernidad: Racionalidad y contingencia en la sociedad moderna. Traduzido por Carlos Fortea Gil. Barcelona: Paidós, 1997.

LUHMANN, Niklas. Die Gesellschaft der Gesellschaft. Frankfurt am Main: Suhrkamp Taschenbuch Verlag, 1998.

INACIO, Estela Maris. Impactos da deriva do herbicida 2,4-D em culturas sensíveis. 2016. 94 f. Tese (Doutorado em Fitotecnia). Universidade de São Paulo, Escola Superior de Agricultura "Luiz de Queiroz", Piracicaba, 2016.

MARTÍNEZ GARCÍA, Jesús Ignácio. Pensar el riesgo. En diálogo con Luhman”, Cuadernos electrónicos de Filosofia del Derecho, n. 21, dic. 2010. Disponível em:

<http://ojs.uv.es/index.php/CEFD/article/view/273>. Acesso em: 09 ago. 2019.

MILARÉ, Édis. Direito do ambiente: a gestão ambiental em foco: doutrina, jurisprudência, glossário. 10. ed. rev., atual e reform., São Paulo: Revista dos Tribunais, 2015.

MOTTA, Ronaldo Seroa da. Economia ambiental. Rio de Janeiro: FGV, 2006.

MORIN, Edgar. Para onde vai o mundo? 2. ed. Petrópolis: Vozes, 2010.

MORIN, Edgar; SILVA, Joaquim Machado. As duas globalizações: complexidade e comunicação, uma pedagogia do presente. 2. ed. Porto Alegre: Sulina/EDIPUCRS, 2002. 
NEUTZLING, Ignácio; ANDRADE, P. F. C.. Uma sociedade Pós-Humana. São Leopoldo: EdUNISINOS, 2009.

OST, François. A Natureza à margem da Lei: a ecología à prova do Direito. Traduzido por Joana Chaves. Lisboa: Instituto Piaget, 1997.

PORTO-GONÇALVES, Carlos Walter. A globalização da natureza e a natureza da globalização. 2. ed. Rio de Janeiro: Civilização Brasileira, 2011.

PRETTO, Edegar (2019) Assembleia Legislativa do Estado do Rio Grande do Sul.

Requerimento de Desarquivamento do Projeto de Lei n. 262/2014. Requerimento de desarquivamento publicado em 01 fev. 2019. Disponível em:

<http://proweb.procergs.com.br/Diario/DA20190221-01-100000/EX20190221-01-100000-PL262-2014.pdf>. Acesso em: 09 ago. 2019.

RIO GRANDE DO SUL. 2019a. GovRS. Novo Sistema de Cadastro Vinícola apresenta dados de colheita e produção da safra 2019. Agricultura. Publicado em 08 jul. 2019. Disponível em:

<https://www.estado.rs.gov.br/novo-sistema-de-cadastro-vinicola-apresenta-dados-de-colheita-eproducao-da-safra-2019>. Acesso em: 03 ago. 2019.

RIO GRANDE DO SUL. 2019b. GovRS. Nova Instrução Normativa sobre 2,4-D inclui município e define prazos. Agricultura. Publicado em 26 jun. 2019. Disponível em:

$<$ https://estado.rs.gov.br/nova-instrucao-normativa-sobre-2-4-d-inclui-municipio-e-define-prazos >. Acesso em: 03 ago. 2019.

ROCHA, Leonel Severo. Da epistemologia jurídica normativista ao construtivismo sistêmico II. In: ROCHA, Leonel Severo; SCHWARTZ, Germano; CLAM, Jean.L. S,; SCHWARTZ, G.; CLAM, J. (Org.). Introdução à teoria do sistema autopoiético do direito. Porto Alegre: Livraria do Advogado, 2005.

ROCHA; Leonel Severo; KING, Michael; SCHWARTZ, Germano. A verdade sobre a autopoiese no direito. Porto Alegre: Livraria do Advogado, 2009.

ROLLSING, Carlos; SOARES, Fernando; COLUSSI, Joana. Conflito entre Porteiras. Zero Hora, Porto Alegre, n. 1.807, Campo e Lavoura, 15 e 16 dez. 2018.

RUSCHEL, René. Ministra da Agricultura transforma o Brasil no paraíso dos agrotóxicos. Carta Capital, Publicado em 02 jun. 2019. Disponível em:

<https://www.cartacapital.com.br/sociedade/ministra-da-agricultura-transforma-o-brasil-noparaiso-dos-agrotoxicos/ >. Acesso em: 08 ago. 2019.

SCHMIDT, R. Institutionen und Instrumente zur Sicherung von Nachhaltigkeit. In: BREITENMOSER, S. et al. (ed.). Human rights, democracy and the rule of law:

Menschenrechte, Demokratie und Rechtsstaat; Droits del'homme, demócratie et Etat de droit: Liber amicorum Luzius Wildhaber. Kehl: Engel, 2007.

SOUZA, Lélio Augusto de; CUNHA, João Paulo Arantes Rodrigues da; PAVANIN, Luiz Alfredo. Deposição do herbicida 2,4-D Amina com diferentes volumes e pontas de pulverização em plantas infestantes. Rev. Ciênc. Agron. Fortaleza, v.43, n..1, jan./mar. 2012. Disponível em: 
<http://www.scielo.br/scielo.php?script=sci_arttext\&pid=S1806-

66902012000100010\&lng=en\&tlng=en\&gathStatIcon=true>. Acesso em: 03 ago. 2019.

TEUBNER, Gunther. El derecho como sistema autopoiético de la sociedad global. Bogotá: Universidad Externado de Colombia, 2005. 